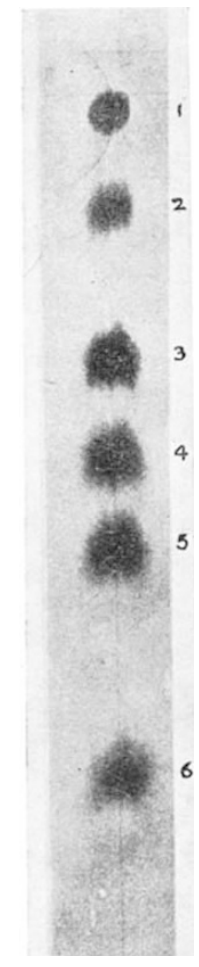

Fig. 2. Chro natogram of a sugar mixture in formic acid-n-butanolwater solvent. The sugars shown are: 1 , ratfinose; 2 , sucrose ; 3 , glucose ; 4 , fructose 5 , xylose ; 6, rhamnose

salmon-coloured spots rapidly turning bright magenta red.

The six varieties of sugar cane examined all show a very similar amino-acid pattern, as can be seen from the photograph, which also indicates the identity of the individual spots shown on the chromatogram. An interesting point is that, in the solvent used, asparagine has a smaller $R_{F}$ value than aspartic acid (the sequence of amino-acids in the control mixture was previously determined by running them separately), whereas in phenol the reverse is true. Similarly, lysine, which has a large $R_{F}$ value in phenol, has a very small $R_{F}$ value in the solvent here described.

A full account of the qualitative and quantitative examination of the amino-acids of sugar cane will be published elsewhere.

The solvent described above can also be used satisfactorily for the chromatographic separation of sugars. Fig. 2 is a photograph of a chromatogram obtained in a 40-hr. run from a mixture of glucose, fructose, sucrose, xylose, rhamnose and raffinose, after development of the chromatogram with aniline phosphate in butanol, a reagent which, as found by Bryson and Mitchell ${ }^{2}$, showed up all the sugars satisfactorily.

\section{F. WIGgins}

J. Howarth Williams

Department of Sugar Chemistry and Technology, Imperial College of Tropical Agriculture, Trinidad, British West Indies.

$$
\text { May } 16 .
$$

'Consden, R., Gordon, A. H., and Martin, A. J. P., Biochem. J., 38, $224(1944)$

${ }^{2}$ Bryson, J. L., and Mitchell, T. J., Nature, 167, 864 (1951).

\section{Plasma Thromboplastin}

WHEN whole normal blood clots in a glass tube, the generation of thrombin can be observed by removing $0 \cdot 1-\mathrm{ml}$. amounts at intervals and adding these to fibrinogen. The clotting times of the fibrinogen samples will record the amount of thrombin present. When this is done, it is found that there is a phase lasting 3-4 min. in which no thrombin can be detected. Thereafter an extremely rapid formation of thrombin occurs, and all the prothrombin is converted to thrombin in 2 or 3 min. This separation of thrombin formation into two phases suggests that there is a powerful intrinsic thromboplastic activity of blood, but that 3-4 min. are required for its formation.

The plasma of a patient deficient in prothrombin but apparently lacking in no other factors was useful for the demonstration of plasma thromboplastin activity. A $1 / 5$ dilution of the patient's plasma was mixed with washed platelets from normal plasma and calcium chloride. At intervals samples were removed from this incubation mixture and added to normal plasma made platelet-deficient by centrifuging, and the mixtures were immediately recalcified. The cloting times of the normal plasma mixtures are shown in Table 1. In this experiment the clotting of the substrate plasma samples certainly cannot be attributed to thrombin transferred from the incubation mixture because very little thrombin was formed. The potency of this thromboplastin requires little emphasis. A $1 / 5$ dilution of plasma mixed with platelets formed a thromboplastin comparable in strength to undiluted brain emulsions.

Table 1. Formation OF THroMropiastin IN PROTHROMETN-DEFICIENT

$0.3 \mathrm{ml}$. of $1 / 5$ plasma was mixed with $0.3 \mathrm{ml}$. platelet suspension (313,000 per c.mm.) and $0.3 \mathrm{ml}$. of $M / 40 \mathrm{CaCl}_{3}$. At intervals $0.1 \mathrm{ml}$. of this incubation mixture was added to $0^{-1} \mathrm{ml}$. of normal plasma and the mixture immediately recalcified with $0.1 \mathrm{ml}$. of $M / 40 \mathrm{CaCl}_{2}$. The clotting times are recorded in seconds. The fibrinogen clotting times give an indication of the amounts of thrombin transferred from

\begin{tabular}{|c|c|c|c|c|c|c|c|c|c|c|}
\hline \multirow[t]{2}{*}{$\begin{array}{l}\text { Incubation } \\
\text { mixture }\end{array}$} & \multirow[t]{2}{*}{$\begin{array}{l}\text { Sub- } \\
\text { strate }\end{array}$} & \multicolumn{9}{|c|}{$\begin{array}{l}\text { Time intervals in minutes for withdrawal } \\
\text { of samples from the incubation mixture }\end{array}$} \\
\hline & & $\frac{1}{2}$ & 1 & 2 & 3 & 4 & 6 & 8 & 16 & 32 \\
\hline $\begin{array}{l}\text { Equal parts } \\
\text { of: } \\
\text { (1) Pro- } \\
\text { thrombin- } \\
\text { deficient } \\
\text { plasma } 1 / 5\end{array}$ & $\begin{array}{l}\text { Recal- } \\
\text { cifled } \\
\text { normal } \\
\text { plasma }\end{array}$ & 37 & 24 & 18 & 16 & 16 & 15 & 15 & 17 & 21 \\
\hline $\begin{array}{l}\text { (2) Platelets } \\
\text { (3) } \mathrm{M} / 40 \\
\mathrm{CaCl}_{0}\end{array}$ & $\underset{\text { gen }}{\text { Fibrino- }}$ & 660 & 163 & 300 & 460 & 570 & 960 & & $0+$ & \\
\hline
\end{tabular}

The factors required for the formation of thromboplastin are platelets, the 'antihæmophilic globulin' and factor VII'. Factor VII is probably identical with serum prothrombin conversion accelerator ${ }^{2}$, convertin ${ }^{3}$, and co-thromboplastin 4 . The formation of this thromboplastin in the factors isolated from normal plasma and serum is shown in Table 2.

Table 2. FORMATION OF THROMEOPIASTIN FROM FACTORS ISOLATED Antihæmophilic goM NORMAL PLASMA AND SERUM saturation with ( $\left.\mathrm{NH}_{4}\right)_{2} \mathrm{SO}_{4}$ from normal plasma previously treated with $\mathrm{AI}(\mathrm{OH})_{3}$ to remove prothrombin

Factor VII. The fraction of serum prepared by $\mathrm{Al}(\mathrm{OH})_{3}$ adsorption and subsequent elution with phosphate buffer at $p \mathrm{H} 8$. platelets : $700,000 \mathrm{cmm}$. prepared from normal plasma.

0.2 ml. amounts of antihæmophillc globulin, factor VII, platelets and $M / 40 \mathrm{CaCl}_{8}$ were mixed, and at intervals $0.1 \mathrm{ml}$. of the incubation mixture was added to $0 \cdot 1 \mathrm{ml}$. of normal plasma and the mixture Thediately recalcified with $0.1 \mathrm{ml}$. of $M / 40 \mathrm{CaCl}_{2}$

\begin{tabular}{|c|c|c|c|c|c|c|c|}
\hline \multirow[t]{2}{*}{ Incubation mixture } & \multirow[t]{2}{*}{ Substrate } & \multicolumn{6}{|c|}{$\begin{array}{l}\text { Time intervals in minutes for } \\
\text { the withdrawal of samples from } \\
\text { the incubation mixture }\end{array}$} \\
\hline & & 1 & 2 & 4 & 8 & 16 & 32 \\
\hline $\begin{array}{l}\text { Equal parts of 'anti- } \\
\text { hæmophilic globu- } \\
\text { lin', factor VII, } \\
\text { platelets, } M / 40 \\
\text { CaCl }_{2}\end{array}$ & $\begin{array}{l}\text { Recalcified } \\
\text { normal } \\
\text { plasma }\end{array}$ & 53 & 51 & 25 & 13 & 13 & 14 \\
\hline
\end{tabular}

It appears that platelets are the main quantitative precursor of thromboplastin, and that the antihæmophilic globulin and factor VII are required in relatively small amounts. This work will be reported in detail elsewhere.

Department of Hæmatology,

ROSEMARY BIGGS

Radcliffe Infirmary,

Oxford. Feb. 20.

1 Koller, F., Loeliger, A., and Duckert, F., Acta Hamatol, 6, 1 (1951). "Alexander, B., de Vries, A., Goldstein, R., and Landwehr, G., Science, 109,545 (1949).

s Owren, P. A., Scand. J. Clin. and Lab. Invest., 3, 168 (1951).

4 Mann, F. 1)., Amer. J. Clin. Path., 19, 861 (1949). 